\title{
REDEFINING 'CLEAN’ SAND BY INTEGRATING FIELD AND LABORATORY DATA ON MIXED SAND-CLAY-EPS RIPPLED-BED TRANSPORT
}

\author{
Baas, Jaco H. ${ }^{1 *}$, Baker, Megan L. ${ }^{1}$, Malarkey, Jonathan ${ }^{1}$, Bass, Sarah, J. ${ }^{2}$, Manning, Andrew \\ J. ${ }^{2,3,4}$, Hope, Julie A. ${ }^{5}$, Peakall, Jeffrey ${ }^{6}$, Lichtman, lan D. ${ }^{7}$, Ye, Leiping ${ }^{3}$, Davies, Alan. G. ${ }^{1}$, \\ Parsons, Daniel. R. ${ }^{3}$, Paterson, David M. ${ }^{8}$, and Thorne, Peter D. ${ }^{7}$ \\ ${ }^{1}$ School of Ocean Sciences, Bangor University, Menai Bridge, Isle of Anglesey, LL59 5AB, United \\ Kingdom \\ ${ }^{2}$ School of Marine Science and Engineering, Plymouth University, PL4 8AA, United Kingdom \\ ${ }^{3}$ Department of Geography, Environment and Earth Sciences, University of Hull, Hull, HU6 7RX, \\ United Kingdom \\ ${ }^{4} \mathrm{HR}$ Wallingford, Howbery Park, Wallingford, OX10 8BA, United Kingdom \\ ${ }^{5}$ Institute of Marine Science, University of Auckland, Private Bag 92019, Auckland, New Zealand \\ ${ }^{6}$ School of Earth and Environment, University of Leeds, LS2 9JT, United Kingdom \\ ${ }^{7}$ National Oceanography Centre, Joseph Proudman Building, 6 Brownlow Street, Liverpool, L3 5DA, \\ United Kingdom \\ ${ }^{8}$ Scottish Oceans Institute, School of Biology, University of St. Andrews, St. Andrews, KY16 8LB, \\ United Kingdom \\ *Email: j.baas@bangor.ac.uk
}




\section{ABSTRACT}

The shape and size of sedimentary bedforms play a key role in the reconstruction of sedimentary processes in modern and ancient environments. Recent laboratory experiments have shown that bedforms in mixed sand-clay develop at a slower rate and often have smaller heights and lengths than equivalent bedforms in pure sand. This is generally attributed to cohesive forces that can be of physical origin, caused by electrostatic forces of attraction between clay minerals, and of biological origin, caused by 'sticky' extracellular polymeric substances (EPS) produced by micro-organisms, such as microalgae (microphytobenthos) and bacteria. In the present paper, we demonstrate, for the first time, that these laboratory experiments are a suitable analogue for current ripples formed by tidal currents on a natural mixed sand-mud-EPS intertidal flat in a macrotidal estuary. Moreover, both the field data and the laboratory data demonstrate that the widely used definitions of 'clean sand' $(<25 \%$ mud: Shepard, 1954) and 'mature sandstone' (arenite, <10-15\% mud: Folk, 1951; Dott, 1964) need to be redefined. Integrated hydrodynamic and bed morphological measurements, collected during a spring tide near Hilbre Island (Dee estuary, NW England), reveal a statistically significant linear decease in current ripple length for progressively higher bed mud contents, and a concurrent change from three-dimensional linguoid to two-dimensional straight-crested ripple plan morphology. These results agree well with observations in laboratory flumes, but the rate of decrease of ripple length was found to differ substantially between the field and the laboratory. Since the formation of ripples under natural conditions is inherently more complex than in the laboratory, five additional controls that might affect current ripple development in estuaries, but have not been accounted for in laboratory experiments, were explored: wave energy, flow energy, clay type, pore water salinity, and bed EPS content. This analysis showed that wave energy and clay type cannot be used to explain the difference in the rate of decrease in ripple length, because surface water waves were weak during the flood and ebb tides preceding the ripple length measurements, and the bed clay contents were too low for clay type to have had a measurable effect on bedform development. Accounting for the differences in flow forcing between the field and experiments, and therefore the relative stage of development with respect to equilibrium ripples, increases the difference between the ripple lengths by $50 \%$. The presence of strongly cohesive EPS in the current ripples on the natural intertidal flat might explain most of the difference in the rate of decrease in ripple length between the field and the laboratory. The effect of pore water salinity on the rate of bedform development cannot be quantified at present, but salinity is postulated herein to have had a smaller influence on the ripple length than bed EPS content. The common presence of clay and EPS in many aqueous sedimentary environments implies that a re-assessment of the role of current ripples and their primary current lamination in predicting and reconstructing flow regimes is necessary, and that models that are valid for pure sand are an 
inappropriate descriptor for more complex mixed sediment. We propose that this re-assessment is necessary at all bed clay contents above $3 \%$. This bed clay content is also recommended as a more appropriate boundary, informed by field-based and laboratory-based sediment dynamics, between 'clean' sand and 'dirty' sand, and between 'arenite' and 'wacke'.

Running title: Redefining 'clean' sand

Keywords: Clean Sand, Arenite, Current Ripples, Mixed Sand-Clay-EPS, Cohesion, Estuary, Intertidal Flat

\section{INTRODUCTION}

In estuaries, the interaction of river flows, tides, and waves leads to more complex particle movement and resulting spatiotemporal distribution of deposits than in many other environments (e.g., Dalrymple \& Choi, 2007; van den Berg et al., 2007). In particular, the common presence of sand mixed with cohesive clay and non-cohesive silt - with silt and clay collectively referred to as mud herein renders the reconstruction of sedimentary processes from bedforms and primary current lamination in estuarine sedimentary facies a challenge, because cohesive forces can have a large influence on the erosion, transport, and deposition of sediment (e.g., Mehta, 2013; Chen et al., 2017). Even small volumes of mud-sized particles in sand - well within 'clean sand' and 'mature sandstone' (arenite), defined as sand with less than 25\% mud by Shepard (1954) and less than 10-15\% mud by Folk (1951) and Dott (1964) - are able to bind sediment particles via electrostatic van der Waals forces, and thereby increase the threshold stress for sediment entrainment from the seabed, promote flocculation of suspended sediment, and change deposit properties, compared to non-cohesive silt and sand. In addition to this physical cohesion, estuaries are also major sites of primary and secondary production, which promotes the development of biological cohesion by organic molecules produced through biological activity (e.g., extracellular polymeric substances, EPS), acting to bind particles through electrostatic interactions, hydrogen bond formation, and cation effects. EPS is produced in sediments by microphytobenthos, chiefly diatoms and cyanobacteria (Underwood \& Paterson, 2003), and bacteria.

At present, cohesion is not sufficiently well-incorporated either into engineering models for estuarine sediment transport or into geological facies models of estuaries (e.g., Mitchener \& Torfs, 1996). Recent experimental work has shown that further fundamental physical sedimentological research is needed to close the knowledge gap with non-cohesive sedimentary dynamics (Baas et al., 2013, 
Malarkey et al., 2015, Schindler et al., 2015; Parsons et al., 2016; Baas et al., 2016). These laboratory studies have highlighted that sedimentary bedforms and their primary current lamination in mixed sand-clay are significantly different from those in pure sand. Fractions of 1-10\% of cohesive clay and less than $0.1 \%$ of EPS within a sand bed are sufficient to increase the development time of current ripples on a flat bed (Baas et al., 2013, Malarkey et al., 2015), and reduce the equilibrium height and length of subaqueous dunes (Schindler et al., 2015; Parsons et al., 2016). This decrease in bedform size, as clay and EPS content are increased, is particularly pronounced for subaqueous dunes (Schindler et al., 2015; Parsons et al., 2016). However, we hypothesise that current ripples in mixed sand-clay-EPS will also be smaller than in pure sand when developed within the time frame of a semidiurnal tide, because the additional time required to reach equilibrium dimensions compared to pure sand ranges from hours to tens of hours (Baas et al., 2013; Malarkey et al., 2015). A key process

during bedform development in mixed sediments is the entrainment of clay, silt, and EPS into suspension from a mixed sand-mud bed, i.e. winnowing (McCrone, 1962), as it may facilitate the bedforms eventually reaching heights and lengths that are similar to their mud-free equivalents. This facilitative process appeared more important for current ripples (Baas et al., 2013; Malarkey et al., 2015) than for dunes (Schindler et al., 2015; Parsons et al., 2016). The above results were based exclusively on controlled laboratory experiments conducted with steady, uniform flow, constant flow depth, well-sorted sand, a single type of clay mineral (kaolinite) and EPS (xanthan gum), and in fresh or brackish water.

The present paper compares, for the first time, the dynamics of experimental small-scale bedforms in mixed sand-clay with those on an intertidal flat in the Dee Estuary, NW England, based on integrated morphological and hydrodynamical data. Firstly, evidence is provided that current ripples found at low slack water at this field site and current ripples in laboratory experiments are influenced by physical and biological cohesion in a similar way. Thereafter, the inherently more complex field conditions are explored to elucidate the underlying processes that control the differences between the field data and the experimental data in the rate of change of current ripple length with changing bed clay and EPS content. Finally, the wider implications of this validation study for predictive sediment transport models, bedform size predictors, and sedimentary facies analysis are discussed.

\section{METHODS}

The field data described here were collected as part of the NERC COHBED (Cohesive Bedforms) project, which examined the dynamics of current-generated bedforms in mixtures of non-cohesive sand and physically and biologically cohesive clay. The COHBED project integrated laboratory experiments with 
a comprehensive set of field measurements in intertidal and subtidal environments near Hilbre Island in the Dee Estuary, NW England (Fig. 1A). The Dee Estuary is funnel-shaped and macrotidal, with a 78 m mean spring tidal range at Hilbre Island. Hilbre Island separates Hilbre Channel from intertidal flats west of the town of West Kirby (Fig. 1A). These tidal flats are flood-dominated and rich in finegrained sediment (Moore et al., 2009). Waves are mainly generated locally within Liverpool Bay, with northwesterly waves having the largest influence on the sedimentary processes in the Dee Estuary (Brown \& Wolf, 2009; Villaret et al., 2011).

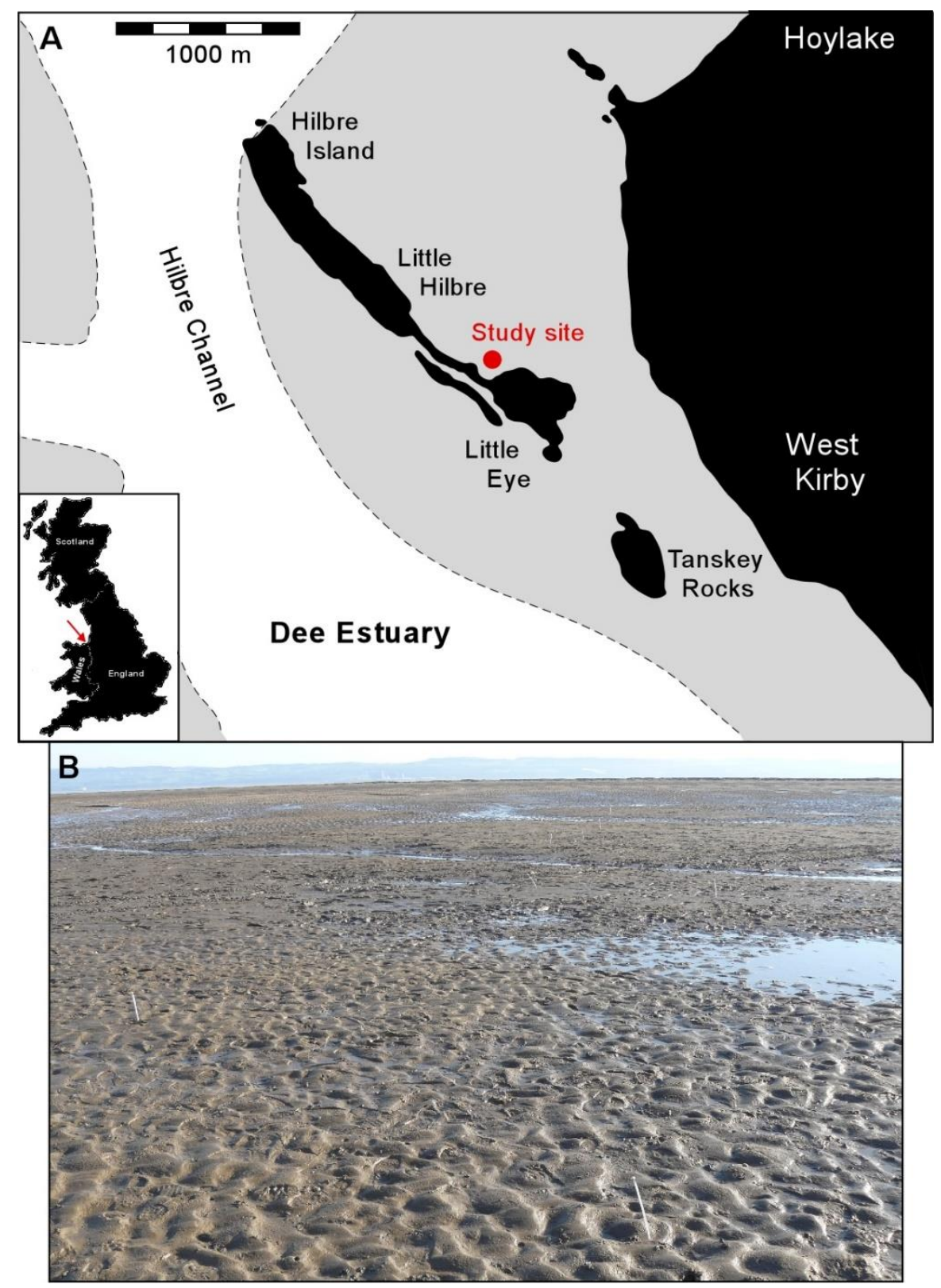

Fig. 1. (A) Schematic map of the Dee Estuary around Hilbre Island, with the main tidal channel in white and the study area located on the grey-coloured intertidal flat to the northwest of Little Hilbre. The four islands are defined by the area above the mean high water mark and by any area of bedrock exposed at low water immediately below this mark. (B) Overview of study site. The ripples in the foreground are approximately $150 \mathrm{~mm}$ long. 
The intertidal flats to the northwest of Little Eye (Fig. 1A) have proven valuable as a natural laboratory for studying bedform dynamics in mixed sand-mud, because of the large variety in sand-mud ratio, ranging from pure sand to sandy mud. During the field campaign in May 2013, the intertidal flats also contained significant amounts of EPS, ranging from $0.02 \%$ to $0.21 \%$ by weight (Lichtman et al., in review). Bed clay and EPS content were linearly correlated $\left(R^{2}=0.41, p<0.05, n=20\right)$

$$
e=0.0105 c+0.0302
$$

where $e$ is the weight percentage of EPS and $c$ is the volume percentage of cohesive clay (Lichtman et al., in review). The present paper uses textural and morphological data collected from a c. $1400 \mathrm{~m}^{2}$ area on May $26^{\text {th }}$ in 2013 when the bed was covered with plane beds and current ripples with different sizes and planform patterns during exposure at low slack water (Fig. 1B). In order to study the relationship between these bedform properties and bed clay and EPS content, 3 flat beds and 12 rippled beds were described visually. Subsequently, bedform lengths were measured (collecting bedform heights within the same low slack water period was not possible), and bulk sediment samples were collected between the crest and base of individual bedforms and down to $20 \mathrm{~mm}$ below the base of these bedforms for subsequent grain size analysis (Malvern 2000 laser particle sizer, Bangor University). This approach allowed the comparison of surface sediments subject to winnowing (loss of fine particles and EPS to the water column) with deeper sediments unaffected by winnowing. The bed sampling also included flat, mud-rich, surfaces without current ripples. For these flat beds, the subsurface samples were collected in the same way as for the rippled beds, i.e. $20 \mathrm{~mm}$ below the surface. These samples were supported by surface scrapes, several millimetres deep, to distinguish undisturbed sediment from sediment that may have been subjected to winnowing at the sedimentwater interface. The sand fraction in the mixed sand-mud at the study site had a median grain diameter of $0.228 \mathrm{~mm}$, and the mud fraction, encompassing all particles finer than $0.063 \mathrm{~mm}$, ranged from $3.8 \%$ to $37.1 \%$. The mud fraction of the ripples at the field site contained $36 \%$ clay minerals by volume (standard deviation: $4 \%, n=7$ ), based on X-ray powder diffraction (XRD) data, obtained using the standard methodology for bulk sediment analysis (Moore \& Reynolds, 1997). In decreasing order of abundance, the clay mineral assemblage comprised illite, chlorite and kaolinite. This $36 \%$ is therefore inferred to represent the cohesive fraction within the mud more accurately than the mud fraction; the remaining $64 \%$ in the mud fraction was dominated by non-cohesive quartz and feldspar. In order to allow a direct comparison with the experimental data of Baas et al. (2013), the bed mud content, $m$, was converted to cohesive clay content using this XRD-derived fraction (Lichtman et al., in review):

$$
c=0.36 \mathrm{~m}
$$


thus yielding cohesive clay fractions ranging from $1.4 \%$ to 13.4 vol\%. Approximately $140 \mathrm{~m}$ northwest of the area where the bedforms were measured, near-bed flow velocities were measured continuously during water cover using two acoustic Doppler velocimeters (ADV) located at $0.25 \mathrm{~m}$ and $0.40 \mathrm{~m}$ above the sediment surface. The temporal resolution of the velocity data used herein was 30 $\mathrm{s}$, derived by bin averaging of the original ADV data acquisition rate of $0.2 \mathrm{~Hz}$. Immediately before the bedforms were studied on May $26^{\text {th }}$, the field site experienced a spring tide with a maximum depthaveraged flow velocity of $0.67 \mathrm{~m} \mathrm{~s}^{-1}$ (based on a total period of submergence of both probes of $c .4 .7$ hours) and southeastward- and northwestward-directed currents during flood and ebb, respectively. The maximum flow depth was $2.73 \mathrm{~m}$ close to high slack water. The depth-averaged velocities were calculated from the vectorially added horizontal components of the ADV data and the flow depth using the standard logarithmic law for wall-bounded shear flow (e.g., van Rijn, 1990). These velocities were then used to calculate the grain-related mobility parameter, $\theta^{\prime}$, described in Equation 6 and 7 below, in order to characterise the bedform development in terms of bed shear stress.

\section{RELATIONSHIP BETWEEN RIPPLE PROPERTIES AND BED MUD CONTENT}

\section{Results}

Table 1 provides the current ripple length data and the corresponding bed mud, cohesive clay and EPS fractions measured at the study site near Little Eye in the Dee Estuary. The mean ripple length, $L$, is plotted against bed mud percentage within the ripples and in the subsurface underneath the ripples in Fig. 2. Figure 2 also provides information on the planform properties of these bedforms, and photographic imagery of the various plan morphologies are shown in Fig. 3.

A statistically significant inverse relationship between the mean ripple length and the bed mud content, $m$, was found for the samples collected from the ripples and from the subsurface (Fig. 2). These relationships are described by a linear trend with $R^{2}$ values of $0.44(p=0.027<0.05, n=12)$ and $0.75(p=0.00058<<0.05, n=12)$, respectively. The mud content in the subsurface was consistently higher than the mud content within the ripples, and this difference rapidly increased, as the ripple length decreased (Fig. 2). For the beds with the lowest mud content, the ripple length was close to the equilibrium length of current ripples in pure sand with a median grain size, $D_{50}$, similar to the present study $\left(D_{50}=0.238 \mathrm{~mm}\right.$ and $L=141 \mathrm{~mm}$ (Baas, 1999) versus $D_{50}=0.228 \mathrm{~mm}$ and $L=142 \mathrm{~mm}$ herein). The smallest ripples, formed at the highest bed mud contents, were $c .20 \mathrm{~mm}$ longer than incipient current ripples in the experimental study of Baas (1999) (Fig. 2). 
Table 1. Summary of morphological and textural field data.

\begin{tabular}{|c|c|c|c|c|c|c|c|c|c|}
\hline \multirow{2}{*}{$\begin{array}{c}\text { Bed } \\
\text { number }\end{array}$} & \multicolumn{2}{|c|}{ Ripple length } & \multicolumn{2}{|c|}{ Bed mud \% } & \multicolumn{2}{|c|}{ Bed clay \% } & \multicolumn{2}{|c|}{ Bed EPS \% } & \multirow{2}{*}{$\begin{array}{l}\text { Bedform } \\
\text { type }\end{array}$} \\
\hline & Mean (mm) & Number & subsurface & ripple * & subsurface & ripple * & subsurface & ripple & \\
\hline 1 & - & - & 23.4 & 11.7 & 8.4 & 4.2 & 0.128 & 0.072 & Flat bed \\
\hline 2 & - & - & 33.8 & 24.0 & 12.2 & 8.6 & 0.178 & 0.131 & Flat bed \\
\hline 3 & - & - & 37.1 & 32.8 & 13.4 & 11.8 & 0.194 & 0.173 & Flat bed \\
\hline 4 & 77 & 15 & 33.5 & 13.7 & 12.1 & 4.9 & 0.177 & 0.081 & 2D ripples \\
\hline 5 & 78 & 9 & 16.8 & 13.3 & 6.0 & 4.8 & 0.096 & 0.079 & 2D ripples \\
\hline 6 & 88 & 12 & 16.9 & 14.3 & 6.1 & 5.1 & 0.097 & 0.084 & 2D ripples \\
\hline 7 & 95 & 11 & 24.7 & 7.9 & 8.9 & 2.8 & 0.134 & 0.053 & 2D ripples \\
\hline 8 & 114 & 9 & 7.2 & 5.3 & 2.6 & 1.9 & 0.050 & 0.041 & $2 D-3 D$ ripples \\
\hline 9 & 116 & 8 & 16.3 & 7.8 & 5.9 & 2.8 & 0.094 & 0.053 & $2 D-3 D$ ripples \\
\hline 10 & 120 & 9 & 6.7 & 6.8 & 2.4 & 2.4 & 0.048 & 0.048 & $2 D-3 D$ ripples \\
\hline 11 & 134 & 7 & 10.9 & 6.5 & 3.9 & 2.3 & 0.068 & 0.047 & $2 D-3 D$ ripples \\
\hline 12 & 123 & 7 & 14.2 & 7.5 & 5.1 & 2.7 & 0.084 & 0.051 & $3 \mathrm{D}$ ripples \\
\hline 13 & 129 & 8 & 5.3 & 3.8 & 1.9 & 1.4 & 0.041 & 0.034 & $3 \mathrm{D}$ ripples \\
\hline 14 & 141 & 7 & 12.7 & 1.6 & 4.6 & 0.6 & 0.076 & 0.023 & $3 \mathrm{D}$ ripples \\
\hline 15 & 143 & 7 & 4.6 & 5.2 & 1.7 & 1.9 & 0.037 & 0.040 & $3 \mathrm{D}$ ripples \\
\hline
\end{tabular}

* Surface scrape for flat beds

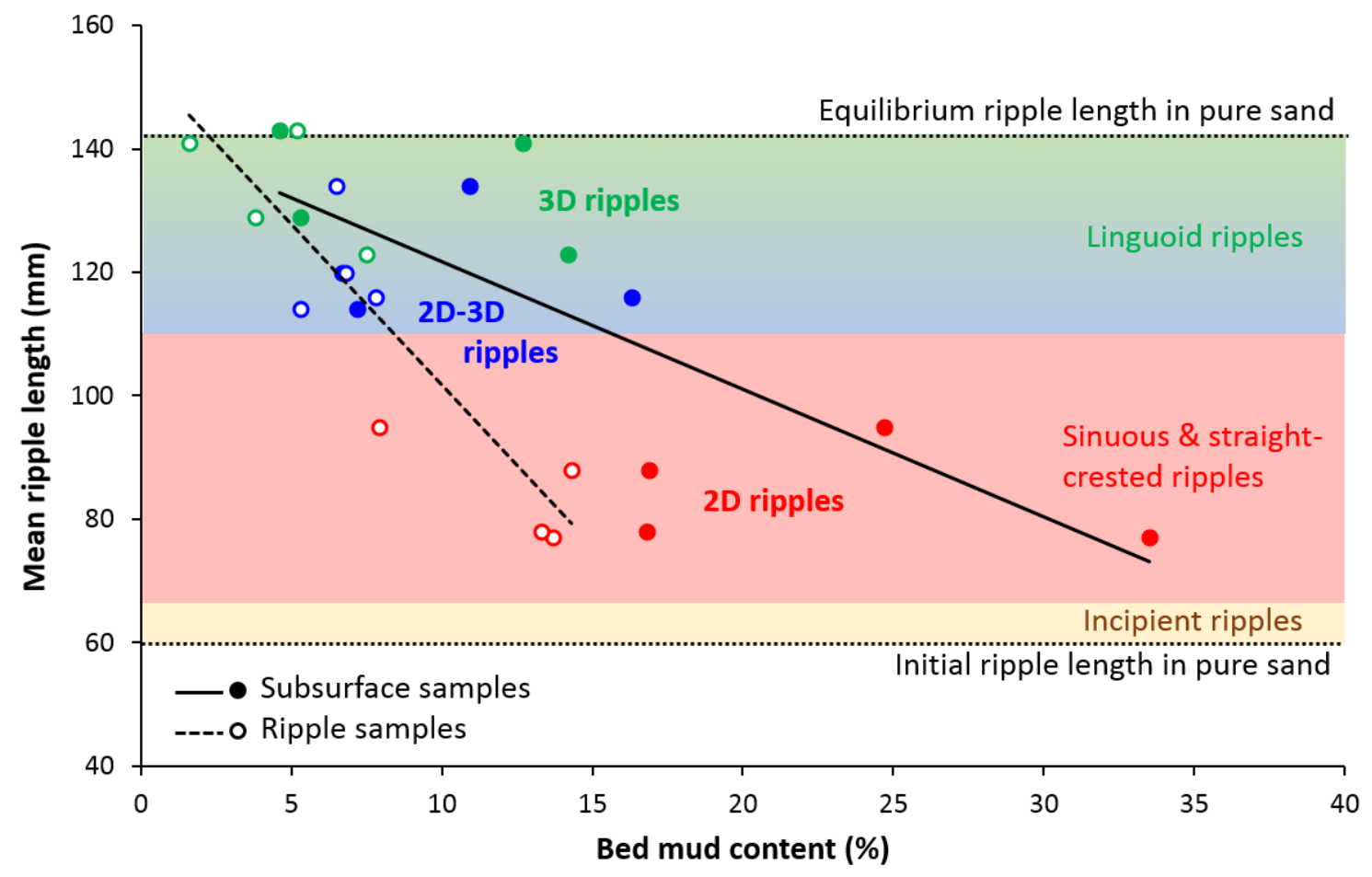

Fig. 2. Mean ripple length against bed mud content for the current ripples at the field site. The black continuous and dashed lines are the linear least-square best fits for the subsurface and the ripple samples, respectively. The colours indicate incipient ripples (yellow), 2D sinuous and straight-crested ripples (red), 2D-3D linguoid ripples (blue), and 3D linguoid ripples (green). The boundaries between these ripple types are from Baas (1999). The horizontal stippled lines denote the initial and equilibrium lengths of current ripples in $0.238 \mathrm{~mm}$ sand (cf. Baas, 1999). 
A. Bed 2: Flat bed, $33.8 \%$ mud

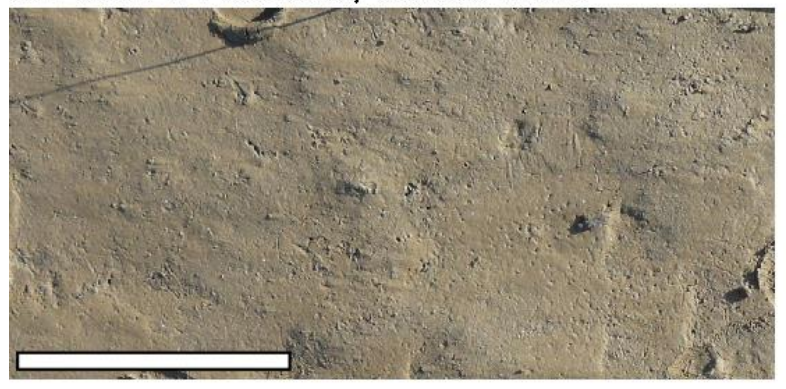

C. Bed 4: 2D ripples, $33.5 \%$ mud

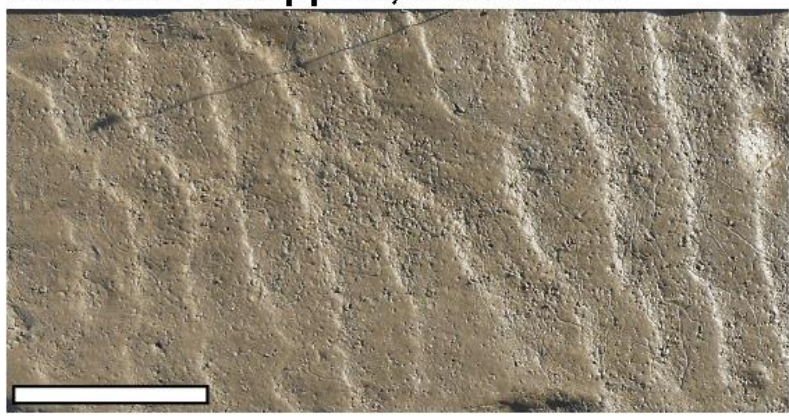

E. Bed 10: 2D-3D ripples, $6.7 \%$ mud

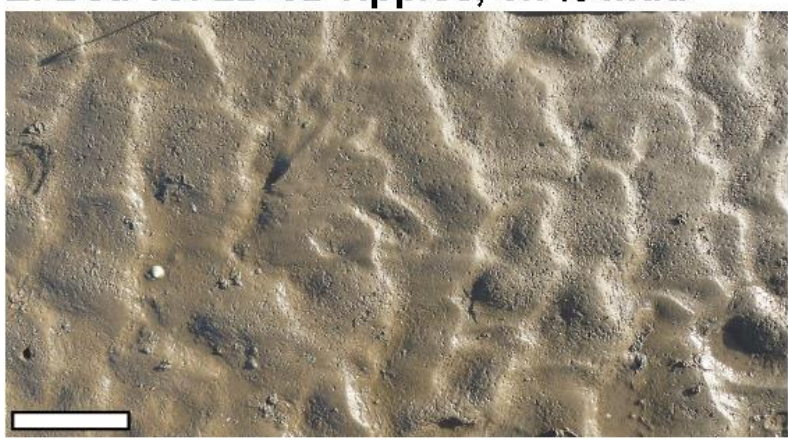

G. Bed 15: 3D ripples, $4.6 \%$ mud

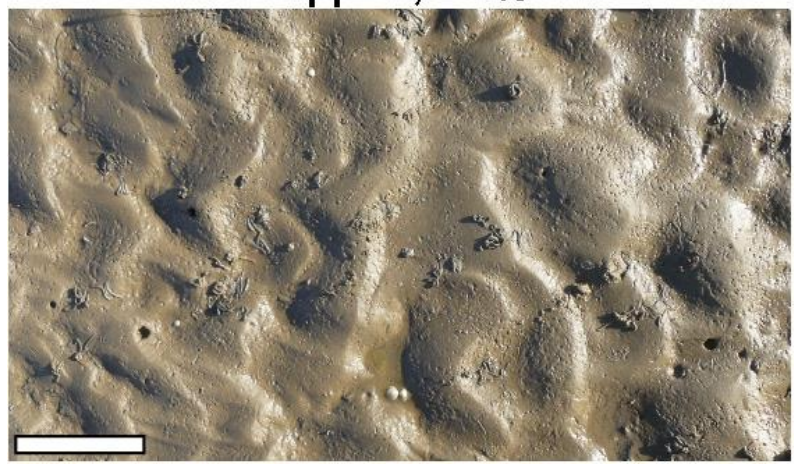

B. Bed 1: Flat bed, $23.4 \%$ mud

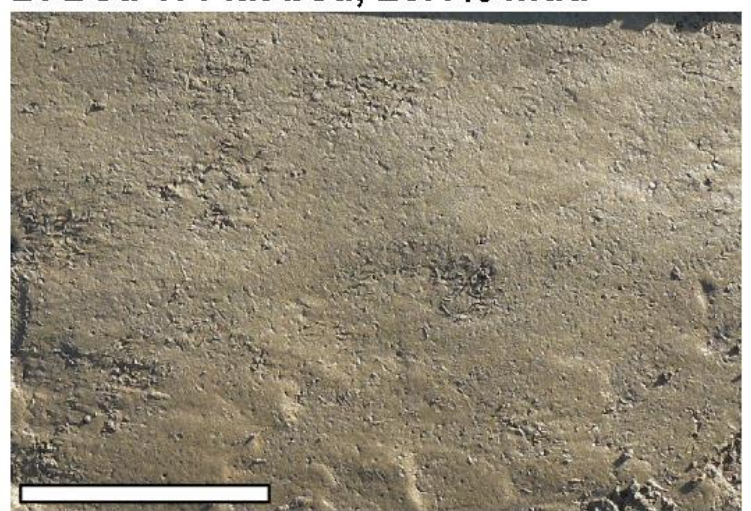

D. Bed $7: 2 \mathrm{D}$ ripples, $24.7 \%$ mud

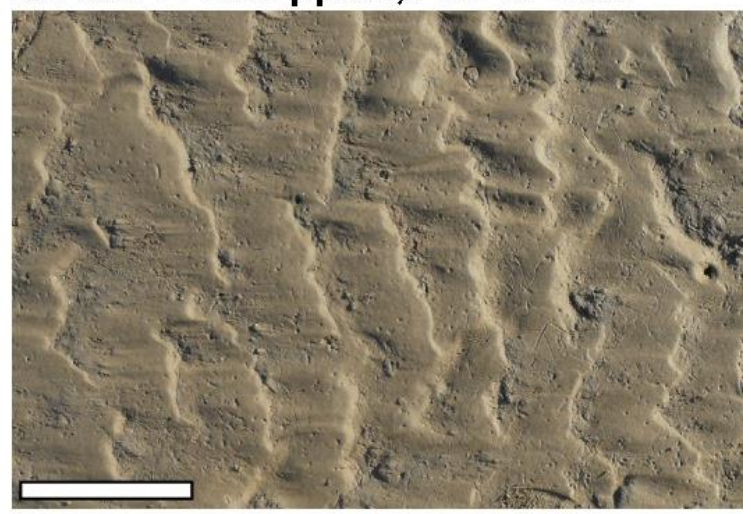

F. Bed $8: 2 D-3 D$ ripples, $7.2 \%$ mud

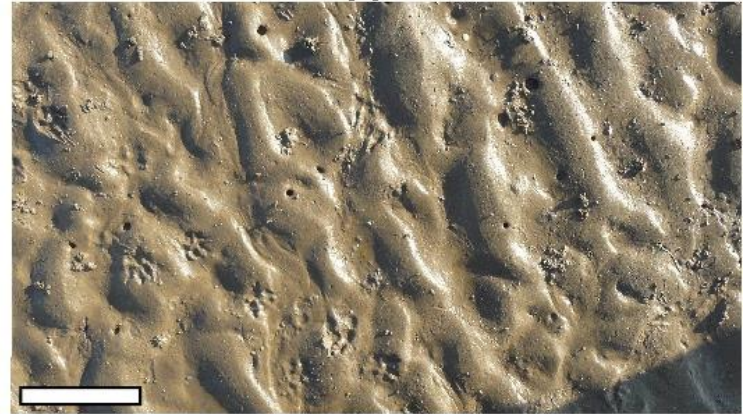

H. Bed 14: 3D ripples, $12.7 \%$ mud

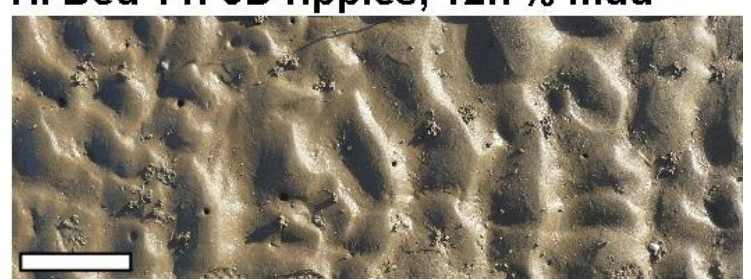

Fig. 3. Field examples of flat beds $(A, B), 2 D$ ripples $(C, D), 2 D-3 D$ ripples $(E, F)$, and $3 D$ ripples $(G, H)$. Bed mud content decreases from $(A, B)$ to $(G, H)$. The percentages in $(A-H)$ denote subsurface mud contents, as shown in Table 1 . The scale bar is $200 \mathrm{~mm}$ long.

Figure 3A-B shows examples of flat surfaces without ripples, which were found in concert with high subsurface mud contents of $23.4 \%, 33.8 \%$, and $37.1 \%$ (Table 1 ). As was the case for the rippled beds, the mud content in the surface scrapes of the flat beds was consistently lower than in the subsurface samples down to $20 \mathrm{~mm}$ (Table 1). The average mud content in this surficial layer was $23 \%$, which was 
higher than any of the mud contents within the ripples. The current ripples with $L \leq 95 \mathrm{~mm}$ (Table 1 ) had straight to weakly sinuous crest lines (Fig. 3C-D); these bedforms are referred to as twodimensional (2D) ripples in the remainder of this paper (Fig. 2). The ripples with a length greater than $110 \mathrm{~mm}$ were either three-dimensional (3D) ripples with linguoid crests (Fig. 3G-H), or transitional between the 2D and 3D ripples (Fig. 3E-F). The beds covered in 2D-3D ripples consisted of patches of linguoid ripples next to ripples with more continuous crests. With one exception, the 2D-3D ripples were shorter in length than the 3D ripples (Fig. 2).

\section{Interpretation}

These field data reveal an inverse linear relationship between bed mud content and ripple length, suggesting that clay minerals within the bed hinder the near-bed movement of these non-cohesive grains (e.g., Mitchener \& Torfs, 1996; Baas et al., 2013). Consequently, the tidal currents were able to form 3D linguoid current ripples only in beds with $m<11 \%$ in the subsurface and $m<6 \%$ within the ripples. At progressively higher bed mud contents, cohesive forces restricted bedform development to smaller 2D-3D and 2D current ripples. The boundary between these ripple types was at bed mud contents in the subsurface and within the ripples of $18 \%$ and $10 \%$, respectively. The beds were too cohesive for any ripple development at subsurface bed mud contents of $c .31 \pm 7 \%$ and surficial mud contents of c. $23 \pm 11 \%$, where $7 \%$ and $11 \%$ denote standard deviations of the mean.

The length and plan morphology of the field ripples correspond remarkably well with the laboratory ripples in $0.238 \mathrm{~mm}$ sand of Baas (1999). The field ripples were too large to be classified as the incipient ripples of Baas (1999), which were up to $67 \mathrm{~mm}$ long. The length of the 2D field ripples was well within the limits of the straight-crested and sinuous ripples of Baas (1999) (Fig. 2), and the 2D-3D ripples and most 3D ripples at the field site correspond in length to the non-equilibrium linguoid ripples of Baas (1999). Only at the lowest bed mud contents the 3D ripples reached lengths that were similar to the equilibrium linguoid ripples in the clay-free sand of Baas (1999).

The difference in mud content in the samples from the subsurface and the ripples agrees with previous studies that associated the development of bedforms with the winnowing of fine particles (e.g., Baas et al., 2013; Schindler et al., 2015; Parsons, et al., 2016; Lichtman et al., in review). The winnowing depth is limited by the height of the bedforms; this explains why the mud content in the subsurface is up to 3 times higher than the mud content in the ripples on the surface (Fig. 2). However, the winnowing of fine sediment in the field was not as efficient as in the laboratory experiments of Baas et al. (2013). Defining the boundaries of winnowing efficiency as $100 \%$ for full removal of bed mud and as $0 \%$ for full retention of mud during bedform development, the average winnowing efficiency at the field site was $35 \%$, compared to $93 \%$ in the experiments of Baas et al. (2013). This low 
winnowing efficiency may be associated with physical and biological processes that counteract winnowing and add and store mud in the bed under field conditions, such as advection of suspended clay particles, deposition of mud flocs during high slack tide, and mixing of clay and silt into the bed by benthic organisms. Winnowing appears to have taken place also on the strongly cohesive flat beds, although this might have been limited to the uppermost millimetres, and the reduction of bed mud content was insufficient to enable ripple formation within the time available. In addition, the production, accumulation, breakdown, and loss of EPS is complex given its multiple sources (bacteria, microphytobenthos and infauna), Therefore, EPS dynamics is likely to be different between the field and laboratory conditions. In laboratory experiments, a proxy of EPS, such as xanthan gum, is often used to provide a known concentration of EPS with more predictable effects. Such proxies provide a useful experimental model but are short of natural conditions. Experiments using natural bacterial populations or mixed assemblages are becoming more common (Chen et al. 2017). Determining the absolute values of EPS concentration in sediments may be problematic in terms of modelling sediment dynamics and one solution is to use a more pragmatic approach of considering negligible (sand), low (mixed sand mud), medium (muddy sand) and high level (mud) effect of EPS, rather than small variations in absolute values.

\section{COMPARISON WITH EXPERIMENTAL MIXED SAND-CLAY RIPPLES}

To facilitate a direct comparison of the ripples at the field site with the ripples in the mixed sand-clay experiments of Baas et al. (2013), the bed mud contents in the subsurface samples collected at the field site, shown in Fig. 2, were converted to cohesive clay contents using Equation 2. For the same reason, the ripple lengths were non-dimensionalised to exclude the influence of grain size on current ripple dimensions (Raudkivi, 1997; Baas, 1999; Soulsby \& Whitehouse, 2005):

$$
\Lambda=\frac{L-L_{0}}{L_{E}-L_{0}}
$$

where $\Lambda$ is the dimensionless ripple length, with $\Lambda=0$ for $L=L_{0}$ and $\Lambda=1$ for $L=L_{E} ; L_{E}$ and $L_{0}$ are the lengths of equilibrium ripples and incipient ripples, first appearing on a flat bed, in pure sand. $L_{E}$ and $L_{0}$ are a function of grain size. Herein, $L_{E}=142 \mathrm{~mm}$ and $L_{0}=60 \mathrm{~mm}$ for the $0.228 \mathrm{~mm}$ sand at the field site, where $L_{0}$ is taken from the experimental data for $0.238 \mathrm{~mm}$ sand of Baas (1999), and $L_{E}=115.9$ $\mathrm{mm}$ and $L_{0}=28.5 \mathrm{~mm}$ for the $0.143 \mathrm{~mm}$ sand used in the experiments of Baas et al. (2013). Baas et al.'s (2013) experiments were conducted with steady, uniform, fresh-water flow at a depth-averaged velocity of $c .0 .36 \mathrm{~m} \mathrm{~s}^{-1}$ and the current ripples were given 2 hours to develop on a flat bed consisting of mixed sand and kaolin clay. 
Figure 4 demonstrates that the dimensionless length of the current ripples was inversely proportional to the initial cohesive clay content in the bed for both the field data and the laboratory data. Moreover, both datasets show a change from 3D ripples via 2D-3D ripples to $2 \mathrm{D}$ ripples, as the initial cohesive clay content in the bed was increased (Baas et al., 2013), and these planforms are demarcated by similar $\Lambda$ values (Fig. 4). We, therefore, conclude that the laboratory experiments provide an appropriate analogue for the effect of cohesive forces on current ripple size and plan morphology under estuarine conditions. However, the rate of change in ripple length was significantly faster for the field ripples than for the experimental ripples, with linear extrapolation predicting a total absence of ripple development at $14 \%$ cohesive clay at the field site and $32 \%$ cohesive clay in the experiments (Fig. 4).

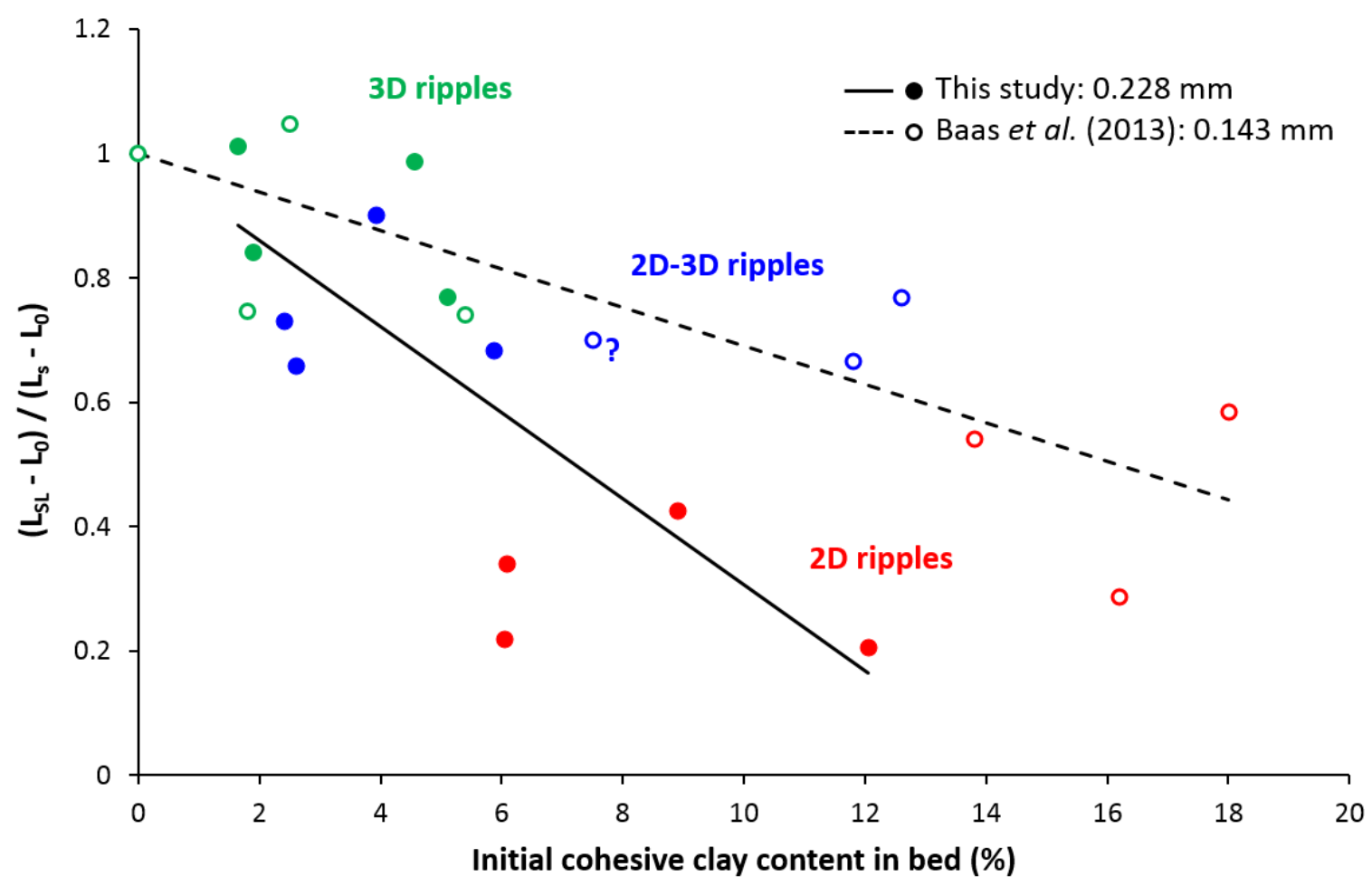

Fig. 4. Dimensionless current ripple length against initial bed cohesive clay content for the ripples at the field site, based on the subsurface samples, and in the experiments of Baas et al. (2013). The black continuous and dashed lines are the linear least-square best fits for the field data and the experimental data, respectively. The colours indicate 2D ripples (red), 2D-3D ripples (blue), and 3D ripples (green). The question mark denotes a rippled bed for which the 2D-3D plan morphology was difficult to ascertain because only side-view photographs were available.

Natural environments are inherently more complex than laboratory flumes (Tolhurst et al., 2009). Hence, this difference in the rate of change in ripple length may be caused by physical and biological variables that were omitted from the flume experiments of Baas et al. (2013). Below, the possible influence on bedform dynamics of the following main variables is assessed: (i) wave energy; (ii) clay mineral type; (iii) flow energy; (iv) bed EPS content; and (v) pore water salinity. Increased wave energy 
and flow energy, i.e., higher tidal flow velocities, are expected to promote the development of current ripples on the intertidal flat, whereas strongly cohesive clay minerals, the presence of biological cohesion in the form of EPS, and seawater salinity should hinder the development of the current ripples. Each of these variables is discussed in detail below, and, if possible, its relative contribution to the difference in the rate of change of ripple length is determined (Fig. 4).

\section{DISCUSSION OF SPECIFIC CONTROLS ON RIPPLE DYNAMICS AT THE FIELD SITE}

\section{Wave energy}

The ripples in the experiments of Baas et al. (2013) were formed from steady, uniform currents, whereas in estuaries bedforms can also be formed from surface water waves. Shallow water waves on intertidal flats may add a near-bed oscillatory stress component to the bed shear stress imposed by tidal flow which results in the formation of combined flow bedforms (e.g., Perillo et al., 2014) during ebb and flood tides and wave ripples around high slack water. However, even waves that are too weak to store evidence of their influence in the bedforms may make sediment particles available for subsequent movement by tidal flows, as the effect of wave forcing on bed shear stress is non-linear (e.g., Malarkey \& Davies, 2012), and thereby can accelerate the development of bedforms on the seabed. This non-linearity is well known for sand beds (e.g., Grant \& Madsen, 1979; Soulsby \& Clarke, 2005) but it should also apply to muddy sand beds.

The temporal resolution of the ADV data is too low to determine if waves were present during the ebb and flood tide immediately before the emergence of the ripples on the intertidal flat. However, a higher-resolution set of pressure sensor and ADV data from a tidal gully $140 \mathrm{~m}$ to the southeast of the study site, described by Lichtman et al. (in review), shows that on May $26^{\text {th }}$ wave heights were less than $0.25 \mathrm{~m}$ and maximum near-bed wave stresses were much lower than the critical limit for the motion of $0.228 \mathrm{~mm}$ sand $\left(0.10 \mathrm{~N} \mathrm{~m}^{-2}\right.$ as opposed to $\left.0.16 \mathrm{~N} \mathrm{~m}^{-2}\right)$. This lack of wave influence on the dynamics of the ripples is supported by the absence of symmetric wave ripples and combined flow ripples at the field site on May 26 2013.

\section{Clay type}

Baas et al. (2013) used kaolinite clay in their experiments, whereas illite clay was dominant at the field site. Illite is more cohesive than kaolinite because illite particles have a larger specific surface area and a larger cation exchange capacity than kaolinite particles (Hillel, 2004; Yong et al., 2012). Mixtures of sand and illite should, therefore, have a higher yield strength than mixtures of sand and kaolinite, and bedforms might develop more readily in mixed sand-kaolinite. However, Baker et al. (2017) showed 
that the difference in yield strength between kaolinite and montmorillonite (incl. bentonite) is small for volumetric clay concentrations below $10 \%$. This agrees with an experimental study by Torfs (1995, in van Ledden, 2001), in which the critical clay content for cohesive behaviour was $3-4 \%$ for both kaolinite and montmorillonite. Since illite is less cohesive than montmorillonite, all the current ripples at the field site were formed at bed clay fractions below $12 \%$, and the subsidiary clay minerals kaolinite and chlorite in the field samples have lower yield strength than the illite, it is inferred that the effect of clay type on the difference in the rate of change of ripple length between the field data and Baas et al.'s (2013) laboratory data was likely to be small.

\section{Flow energy}

The experiments of Baas et al. (2013) were conducted at a constant depth-averaged flow velocity of c. $0.36 \mathrm{~m} \mathrm{~s}^{-1}$, whereas the field site was subjected to unsteady flow with a maximum depth-averaged flow velocity of $0.67 \mathrm{~m} \mathrm{~s}^{-1}$ (Fig. 5). As the rate of bedform development increases non-linearly with flow velocity (Baas, 1994, 1999), the current ripples at the field site could have been preserved at the end of ebb flow in a different development stage than the mixed sand-clay ripples of Baas et al. (2013). This development stage would render these ripples non-equilibrium bedforms sensu Baas (1994). Before testing this hypothesis, it is important to consider the alternative that the ripples on the intertidal flat were smaller than ripples in the equivalent clay-free sand because they are equilibrium bedforms (Baas, 1994) with lengths that are inversely proportional to bed clay content. Baas et al. (2013) discussed both possibilities without stating a preference, but, subsequently, Malarkey et al. (2015) provided experimental evidence that current ripples in cohesive mixtures of sand and EPS reach equilibrium heights and lengths that are similar to those in non-cohesive sand, provided that the flow duration is sufficiently long. Assuming that this evidence can be extrapolated from biological cohesion to physical cohesion, the mathematical model of Oost \& Baas (1994) and Baas et al. (2000) for current ripple development in unsteady flow was used to compare the development stage of the ripples at the field site and in the experiments of Baas et al. (2013):

$$
\begin{aligned}
& \frac{L_{S L}-L_{0}}{L_{E}-L_{0}}=1-0.01^{S_{L}} \wedge S_{L}=\int_{0}^{T} \frac{d t}{T_{E}(t)} \\
& T_{E}=\left(\frac{\theta^{\prime}-\theta_{c}}{a}\right)^{-\frac{1}{b}}
\end{aligned}
$$



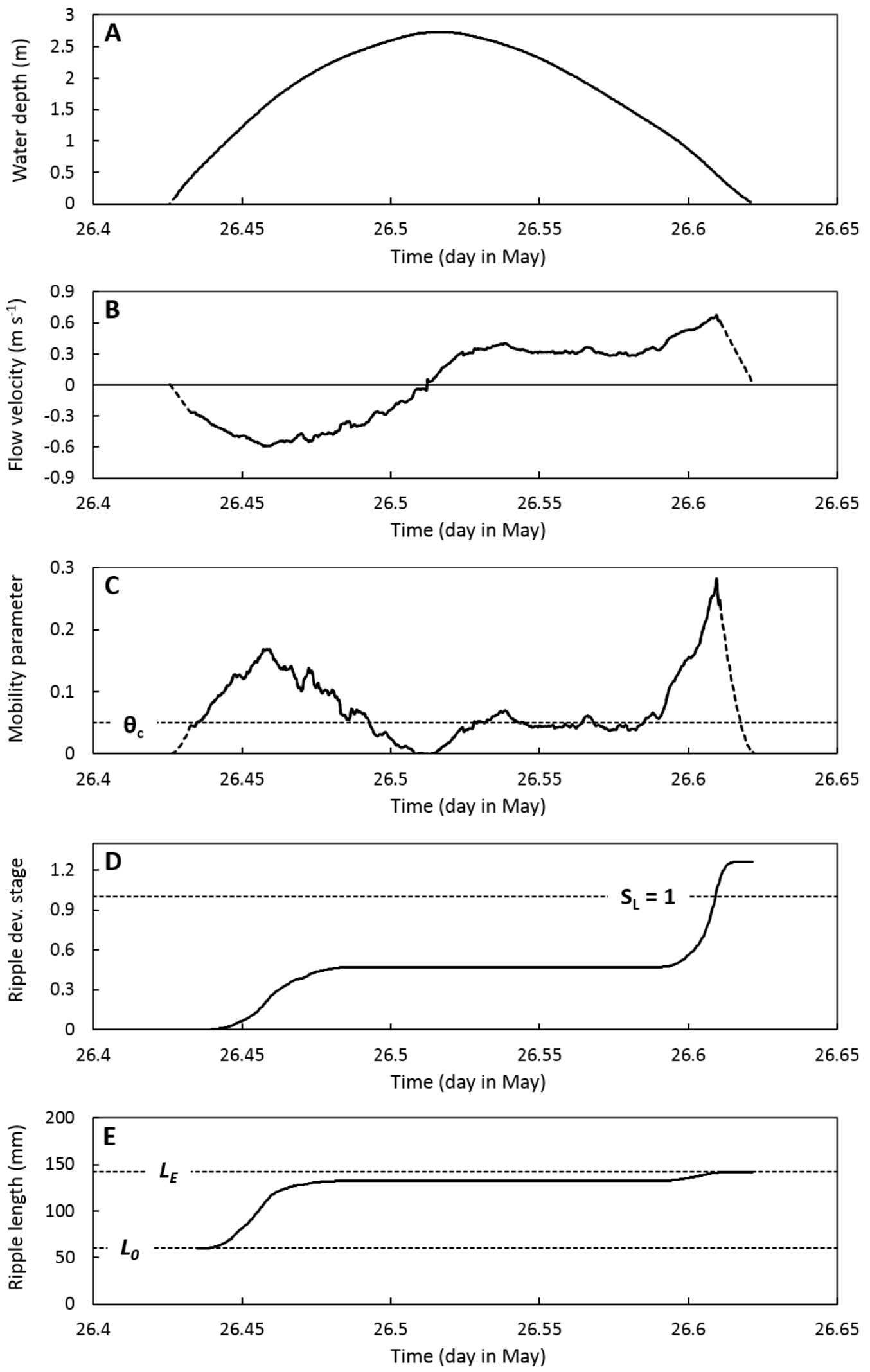

Fig. 5. Summary of the field data, collected on May $26^{\text {th }}$, 2013. (A) water depth, (B) depth-averaged flow velocity, (C) grainrelated mobility parameter, (D) cumulative ripple length development stage, (E) predicted temporal development of ripple length. The dashed lines in (B) and (C) denote linear extrapolations. $\theta_{c}=0.0508$ is critical grain-related mobility parameter; $L_{E}=142 \mathrm{~mm}$ is equilibrium ripple length; $L_{0}=60 \mathrm{~mm}$ is initial ripple length. $S_{L}$ is cumulative ripple length development stage. 
In Equation 4, $L_{S L}$ is the ripple length at time $T$ (in hours), $T$ is the flow duration in hours, $S_{L}$ is the cumulative development stage of ripple length, and $T_{E}(t)$ is the equilibrium time in hours as a function of time $t$, i.e. the time needed to reach equilibrium ripple length at the acting current strength. $S_{L}=0$ for a flat bed, and $S_{L} \geq 1$ for equilibrium ripples. In Equation $5, T_{E}$ is related to the inverse of the flow forcing:

$$
\begin{aligned}
\theta^{\prime} & =\frac{U^{2}}{\left(\rho_{s} / \rho-1\right) C^{\prime 2} D_{50}} \\
C^{\prime} & =18 \log \left(\frac{12 h}{3 D_{90}}\right)
\end{aligned}
$$

where $\theta^{\prime}$ is the grain-related mobility parameter, $U$ is the depth-averaged flow velocity, $\rho_{s}=2650 \mathrm{~kg}$ $\mathrm{m}^{-3}$ is the sediment density, $\rho=1027 \mathrm{~kg} \mathrm{~m}^{-3}$ is the density of seawater, $D_{50}$ is the median grain size of the bed sand fraction, $C^{\prime}$ is the grain-related Chézy coefficient, $h$ is the flow depth, and $D_{90}$ is the 90percentile of the grain-size distribution of the sand fraction (herein, $D_{90}=0.364 \mathrm{~mm}$ ).

In Equation 5, $\theta_{c}$ represents the critical mobility parameter for particle entrainment, parameterised from the Shields curve (Shields, 1936) by Soulsby (1997):

$$
\begin{aligned}
& \theta_{c}=\frac{0.3}{1+1.2 D_{*}}+0.055\left(1-e^{-0.02 D_{*}}\right) \\
& D_{*}=\left(\frac{\left(\rho_{s} / \rho-1\right) g}{v^{2}}\right)^{1 / 3} D_{50}
\end{aligned}
$$

where $D *$ is the dimensionless grain size parameter, $g=9.81 \mathrm{~m} \mathrm{~s}^{-2}$ is the constant due to gravity, and $v=1.37 \times 10^{-6} \mathrm{~m}^{2} \mathrm{~s}^{-1}$ is the kinematic viscosity of seawater at $10^{\circ} \mathrm{C}$. The coefficients $a$ and $b$ in Equation 5 are grain-size dependent. For the field site with $0.228 \mathrm{~mm}$ sand herein, $a=0.112$ and $b=0.473$, which are linearly interpolated from values for $0.095 \mathrm{~mm}$ and $0.238 \mathrm{~mm}$ sand (cf., Baas et al., 2000). Equations 4 to 9 were used to predict the final length of clay-free current ripples developing on a flat bed during the flood and ebb tides immediately preceding the data collection (Fig. 5). The grainrelated mobility parameter (Fig. 5C) was calculated from the water depth (Fig. 5A) and the depthaveraged flow velocity (Fig. 5B). In turn, $\theta^{\prime}$ was used to predict the cumulative ripple development stage (Fig. 5D) and finally the temporal development of ripple length (Fig. 5E). As expected, the highest rates of ripple length development occurred around maximum flood and maximum ebb flow. The 
ripples were predicted to attain their full equilibrium length after of $4.4 \mathrm{~h}$ of the available 4.7 hours of tidal flow (Fig. 5D-E). The model predicts $S_{L}=1.263$ at time T, with $L_{S L}=141.8 \mathrm{~mm}$. However, the age of the sandiest ripples at the field site might extend further back in time, as it is unknown how long these bedforms had been at equilibrium. Yet, it is unlikely that these bedforms formed more than three or four principal lunar semi-diurnal tidal cycles before the ripple length data were collected because strong waves on May $24^{\text {th }}$ generated wave ripples, combined flow ripples, and upper-stage plane beds in the tidal gully of Lichtman et al. (in review). The model predictions for $S_{L}$ and $L_{S L}$ in Fig. 5D-E should, therefore, be considered minimum values.

In the experiments of Baas et al. (2013), the equilibrium length of the current ripples in pure sand, based on $L_{S L}=0.99 L_{E}(c f .$, Equation 4), was reached at $2.7 \mathrm{~h}$. All the experiments with mixed sand-clay were halted after $2 \mathrm{~h}$. Hence, a simple division of these durations (Equation 4) yields a cumulative ripple length development stage of 0.741 , which applies to all the bed clay fractions. This $S_{L}$-value is smaller than the predicted minimum cumulative development stage of 1.263 for the present study. Figure 4 should therefore be used to compare ripple lengths only after this difference in the development stage is accounted for. In order to better match the field data with the experimental data, Equation 4 was applied in modified form to predict the length of the mixed sand-clay ripples in the field for $S_{L}=0.741$ :

$$
\frac{L_{0.741}-L_{0}}{L_{E}-L_{0}}=1-\left(\frac{L_{E}-L_{1.263}}{L_{E}-L_{0}}\right)^{\frac{0.741}{1.263}}
$$

where $L_{0.741}$ and $L_{1.263}$ are the ripple lengths for each bed cohesive clay content, and for $S_{L}=0.741$ and $S_{L}=1.263$, respectively. Equation 10 again assumes that the 2D, 2D-3D, and small 3D bedforms at the field site are non-equilibrium equivalents of clay-free equilibrium ripples in $0.228 \mathrm{~mm}$ sand, and that the tidal flow started to affect the bed at the study site simultaneously for all bed clay contents including a possible delay in the first appearance of the bedforms (cf. Baas et al., 2013). Replotting the field data for $L_{0.741}$ (Fig. 6) reveals that differences in flow forcing cause a $50 \%$ increase in the difference in $\Lambda$ between the field data and the laboratory data. This $50 \%$ increase should be considered a minimum in the difference in $\Lambda$ because Equation 10 does not take into account the earlier mentioned possibility that the ripples started to form before the last phase of tidal inundation and thus had even lower $\Lambda$-values at $S_{L}=0.741$ than the laboratory ripples.

\section{Bed EPS content}

An important difference between the field data and the laboratory data of Baas et al. (2013) is the lack of biological cohesion in the flume experiments. The EPS concentrations in the bed samples from the field site were not measured, but Equation 1 can be used to make a qualitative assessment of the 
effect of EPS on the remaining difference in the rate of change of dimensionless ripple length with increasing bed clay content (Fig. 6). The subsurface samples contained up to $0.194 \%$ EPS (Table 1 ). The development of the ripples appears to have been limited to subsurface EPS contents below c. $0.177 \%$ EPS, and the ripples contained up to $0.084 \%$ EPS after winnowing. These threshold values match the experimental data of Malarkey et al. (2015), in which current ripples ceased to form between $e=$ $0.125 \%$ and $e=0.250 \%$ on flat beds that contained mixed sand, EPS, and fresh water. However, a more detailed comparison between the field data and Malarkey et al.'s (2015) data is not possible because these sand-EPS experiments were conducted without any cohesive clay, and with xanthan gum, which is an EPS proxy that is unlikely to be fully representative for the type of EPS present in the Dee estuary (cf., van de Lageweg et al., 2017). Nonetheless, Malarkey et al. (2015) showed that EPS have a strong influence on bedform dynamics, with concentrations of EPS similar to those found at the study site reducing the rate of development of the current ripples by orders of magnitude. The EPS might, therefore, also have had a strong influence on the development of the current ripples at the study site that could explain most of the difference in the rate of change of $\Lambda$ between the field and laboratory data (Fig. 6). Clearly, more field data are needed, in combination with tailored flume experiments on bedform development in mixed sand-clay-EPS, to determine the precise influence of EPS for a wider range of boundary conditions.

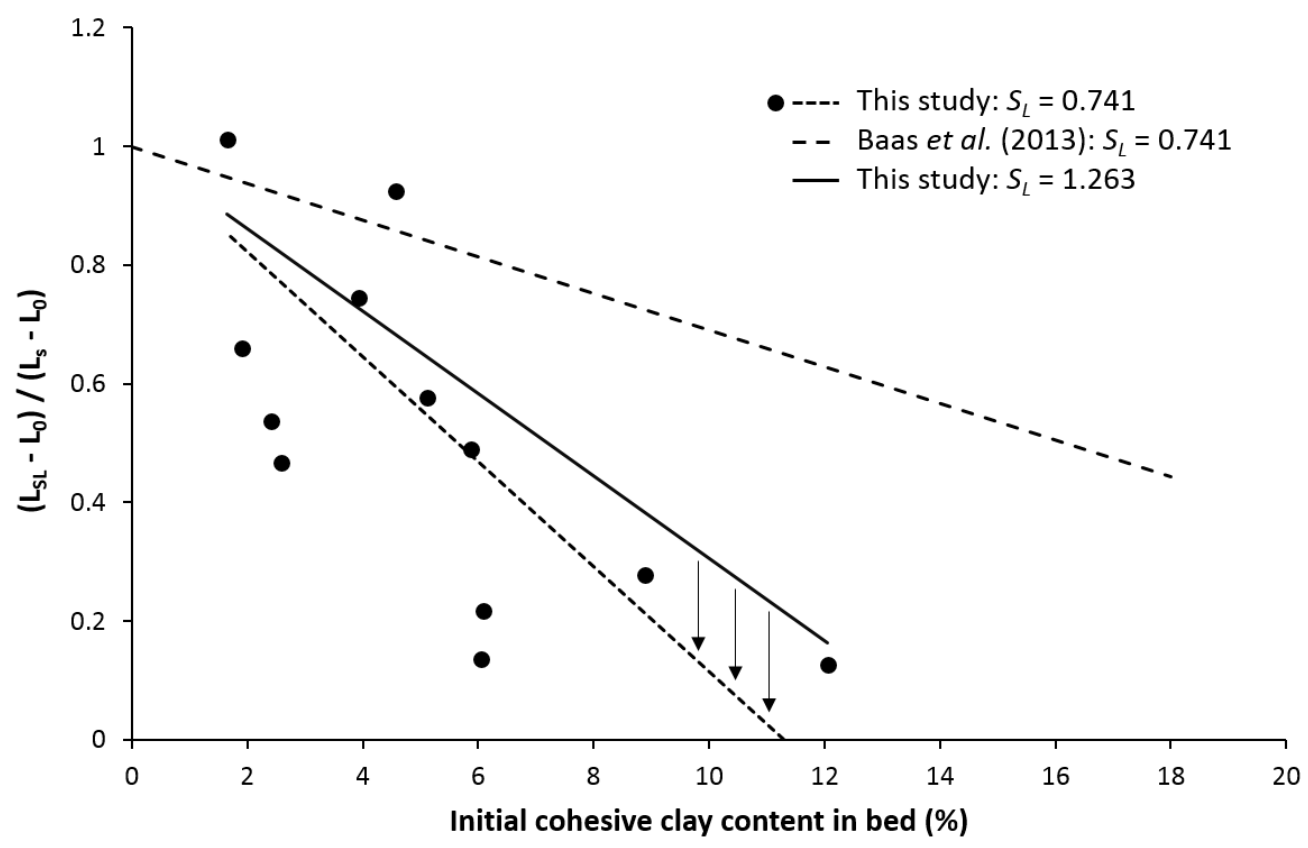

Fig. 6. Dimensionless current ripple length against initial bed clay content for the ripples at the field site and in the experiments of Baas et al. (2013) after accounting for differences in flow forcing. The continuous and long-dashed lines are the linear least-square best fits for the field data and the experimental data, as in Fig. 4. The short-dashed line is the linear least-square best fit for the predicted bedform lengths at the field site (black dots) at $S_{L}=0.741$. The arrows denote the change in dimensionless ripple length from $S_{L}=1.263$ to $S_{L}=0.741$. 


\section{Water salinity}

The laboratory experiments of Baas et al. (2013) were conducted with fresh water, whereas the current ripples at the field site were formed in seawater. Salinity is well known to promote the formation of cohesive bonds between clay particles through the availability of cations that neutralise the negatively charged edges of clay platelets and therewith stimulate the attraction of these platelets by van der Waals forces (e.g., Manning et al., 2007; Mehta, 2013). This physicochemical attraction leads to the development of clay aggregates, i.e. floccules, that often have higher settling velocities than their constituent particles. Experimental studies typically find a positive correlation between erosion threshold and salinity for muddy sediments (e.g., Kandiah, 1974; Parchure \& Mehta, 1985). However, no significant statistical relationship between salinity and critical shear stress existed for mixed sand-EPS in the laboratory experiments of van de Lageweg et al. (2017). Furthermore, the relationship between salinity and critical shear stress for sediment motion in field studies is ambiguous. Amos et al. (2003) found no difference in the threshold of erosion for natural muds in marine and freshwater environments, whereas Debnath et al. (2007) obtained a negative correlation between salinity and erosion rate for natural muds, and Spears et al. (2008) found that the erosion threshold increased seaward with salinity in the Eden Estuary (south-eastern Scotland). These differences between the field studies, in comparison to theoretical and experimental approaches, suggests that at least in some cases the effect of salinity on bed erosion is masked by other parameters in the natural environment, such as bed density and EPS content (e.g., Grabowski et al., 2011). For the present study, it is postulated that the difference in the rate of decrease of dimensionless ripple length, as cohesive clay content is increased, between the field data and the experimental data (Fig. 6 ) is partly caused by the difference in pore water salinity. Some support is provided by unpublished pilot experiments of the authors, which show that mixed sand-EPS current ripples take longer to develop in seawater than in fresh water. However, further experiments are needed to determine how much of the difference between the field data and the laboratory data (Fig. 6) can be explained by differences in pore water salinity. We expect salinity to have a smaller effect than EPS, considering the strong inverse relationship between ripple development rate and bed EPS content (Malarkey et al., 2015).

\section{WIDER IMPLICATIONS}

Frequency of occurrence of equilibrium and non-equilibrium current ripples 
At the field site, the presence of cohesive clay and EPS was found to have had the greatest influence on the growth rate and size of the current ripples, followed in decreasing order of influence by flow forcing and salinity, whereas the influence of wave energy and clay type was small to negligible. However, the relative contribution of these controlling variables is likely to be unique to the measurement period at the study site. Table 2 summarises the more general importance of each variable in mixed sand-clay-EPS environments.

Physical and biological cohesion are expected to have a strong influence on current ripple dynamics (Table 2), because small fractions of clay and EPS, akin to most aqueous environments, are sufficient to reduce current ripple size, promote two-dimensionality of ripples, and delay ripple growth. In environments where the currents and waves are stronger than at the field site, e.g., in tidal channels and on wave-facing beaches, sand-rich equilibrium bedforms are probably more common, because stronger hydrodynamic forcing promotes the development rate of the bedforms, assisted by a faster rate of winnowing of clay and EPS from the bed. This raises the question if non-equilibrium mixed sand-clay-EPS ripples will dominate the bed when the currents are weaker than at the field site. In fact, this weaker hydrodynamic forcing should be the more likely scenario because the mean spring tidal range of 7-8 $\mathrm{m}$ in the Dee estuary is amongst the largest in Europe, and the field data were collected at spring tide in this macrotidal estuary. Under such circumstances, maximum tidal velocities are higher than in many microtidal, mesotidal and other macrotidal environments. However, since the formation of the current ripples in this study was restricted to bed clay and EPS fractions of up to only $12 \%$ and $0.2 \%$, we infer that mixed sand-clay-EPS ripples form less readily on sand-mud tidal flats in these lower-energy environments, even under the consideration that these percentages might vary with clay type, EPS type, and flow forcing. Assuming that it is possible to form bedforms at all in such conditions, many tidal cycles would be needed to form recognisable mixed sand-clay-EPS ripples, and their preservation would depend on the frequency of occurrence of processes that destroy these bedforms, such as bioturbation and storm waves. Mixed sand-clay-EPS ripples might be restricted to a narrow strip at the boundary between sandy tidal channels and muddy tidal flats in estuaries with a smaller tidal range than the study site. Likewise, it is anticipated that during neap tides in the Dee Estuary, and in other macrotidal estuaries with a similar tidal range, the mixed sand-clay-EPS bedforms shift from intertidal flats towards subtidal channels and other areas of confined tidal flow.

Although the effect of pore water salinity on current ripple growth rate and size is not fully understood at present (Table 2), the concentration of cations in brackish water and seawater are expected to be large enough to cause longer delays in the development of mixed sand-clay-EPS current ripples in fully marine and estuarine environments than in freshwater environments, such as rivers and lakes. It is therefore hypothesised for the benefit of future studies that equilibrium mixed sand-clay-EPS 
bedforms are more common in fresh water. At the field site, the influence of clay type was found to be small (Table 2). However, tidal flows with significantly larger velocities than at the field site, and possibly helped by surface water waves, might be able to form current ripples at $c>12 \%$ and $e>0.2 \%$, for which differences in yield strength between clay types start to play a more significant role in causing differences in bed cohesion (Baker et al., 2017), and therefore bedform development rate.

Table 2. Summary of relative contribution of factors controlling bedform development in mixed sand-clay-EPS.

\begin{tabular}{lll} 
Controlling factor & Relative contribution & Relative contribution \\
& This study & Generalised \\
\hline Cohesive clay & Large & Large \\
EPS & Probably large & Probably large \\
Flow energy & Large & Variable \\
Water salinity & Unknown, perhaps smaller than EPS & Unknown, perhaps smaller than EPS \\
Wave energy & None & Variable \\
Clay type & Small & Small
\end{tabular}

\section{Implications for studies in modern environments}

Accurate knowledge of the geotechnical, morphological, and biological properties of the seabed is essential for the quantification of near-bed sediment transport in modern environments. These properties include the sediment size, the cohesive strength of the bed, the critical shear stress for sediment motion, and the size and migration rate of bedforms. The rate of bedload transport per unit width, $q_{b}$, can be calculated based on the volumetric sediment concentration, $C_{b}$, the particle velocity, $u_{p}$, and the saltation height of the particles, $\delta_{b}$ (van Rijn, 1993):

$$
q_{b}=C_{b} u_{p} \delta_{b}
$$

or on the current ripple height, $H$, and the current ripple migration rate, $u_{r}$ (van den Berg, 1987):

$$
q_{b}=0.6(1-P) u_{r} H
$$

where $P$ is the bed porosity. Equation 11 was expressed by van Rijn (1993) also in terms of flow forcing and sediment size:

$$
q_{b}=0.053 \sqrt{\left(\rho_{s} / \rho\right) g} D_{50}^{1.5} D_{*}^{-0.3}\left(\frac{\tau_{b}-\tau_{b, c}}{\tau_{b, c}}\right)^{2.1}
$$


where $\tau_{b}$ is the bed shear stress, and $\tau_{b, c}$ is the critical bed shear stress according to Soulsby (1997). Baas et al. (2000) found a power-law relationship between flow forcing and ripple migration rate for Equation 12, which in modified form can be written as:

$$
u_{r}=\alpha\left(\theta^{\prime}-\theta_{c}\right)^{\beta}
$$

where $\alpha$ and $\beta$ are coefficients dependent on sediment size.

Equations 11-14, as well as other bedload transport equations, have been used successfully for cohesionless sand, albeit with large degrees of uncertainty. The fact that "it is hardly possible to predict the transport rate with an inaccuracy of less than factor 2" (van Rijn, 1993) might result in part from the lack of parameterisation of the effect of physical and biological cohesion in these equations. The present study, combined with the recent laboratory studies, on bedform development in mixed sand-clay (e.g., Baas et al., 2013; Malarkey et al., 2015; Parsons et al., 2016) suggests that predictions of $q_{b}$ could be vastly improved if cohesive forces were included in bedload transport equations. Insufficient data are available at present to achieve this, but these improvements would require the modification of $\tau_{b, c}$ in Equation 13 and $\theta_{c}$ in Equations 14 for cohesive forces in the bed, even at several percent of clay and hundredths of a percent of EPS. An improved parameterisation of ripple height in Equation 12 is also essential, because existing mathematical predictors for the size of current ripples (Raudkivi, 1997; Baas, 1999; Soulsby \& Whitehouse, 2005), which relate the equilibrium height (and length) of the ripples to the median sediment size within the ripples, have been developed only for non-cohesive sand. Hence, these predictors are unlikely to be sufficiently accurate for mixed sandclay-EPS.

The present study strengthens the evidence collected in previous studies (e.g., Baas 1994, 1999) that current ripples are often smaller in size, and more two-dimensional in planform, than those predicted from the size of the sand particles in the bed alone. In other words, the common presence of cohesive clay and EPS in the natural environment increases the likelihood of finding smaller ripples with nonequilibrium planforms. By using an equation for the development of ripple height from a flat bed in clay-free $0.228 \mathrm{~mm}$ sand (e.g., Baas, 1999), similar to Equations 4 and 5 but with an initial height, $H_{0}$, equal to zero, it can be shown that the smallest ripples in the study area were $c .4 \mathrm{~mm}$ high, and the equilibrium height, $H_{E}$, was $17 \mathrm{~mm}$. For this $13 \mathrm{~mm}$ difference in ripple height alone Equation 12 would overpredict the bedload transport rate by a factor 4 , if the effect of cohesion is ignored. The presence of clay and EPS also increases $\theta_{c}$; this is likely to further worsen this overprediction. Figure 7 provides an estimation of the possible error in $\theta_{c}$ for kaolin clay and the EPS-proxy xanthan gum, based on flume experiments in which the critical Shields parameter was determined for mixed sand-clay-EPS by gradually increasing the bed shear stress imposed by a steady, uniform flow until a downstream 
bedload trap started to collect sediment particles (See Appendix A for further details). For up to $1 \%$ xanthan gum and up to $30 \%$ kaolin, $\theta_{c}$ was up to $73 \%$ and $83 \%$ higher than in the non-cohesive reference sand (Fig. 7). The combined effect of biological and physical cohesion led to an increase in $\theta_{c}$ by up to $123 \%$. At the field site, where the current ripples formed only below $12 \%$ clay and below $0.2 \%$ EPS, Fig. 7 suggests a maximum increase in $\theta_{c}$ by $27 \%$ for the mixed sand-clay-EPS. It should be emphasised, however, that this percentage increase is merely an approximation of the combined effect of physical and biological cohesion on $\theta_{c}$ because the experiments were conducted with types of sand, clay, and EPS that were different from those at the field site.

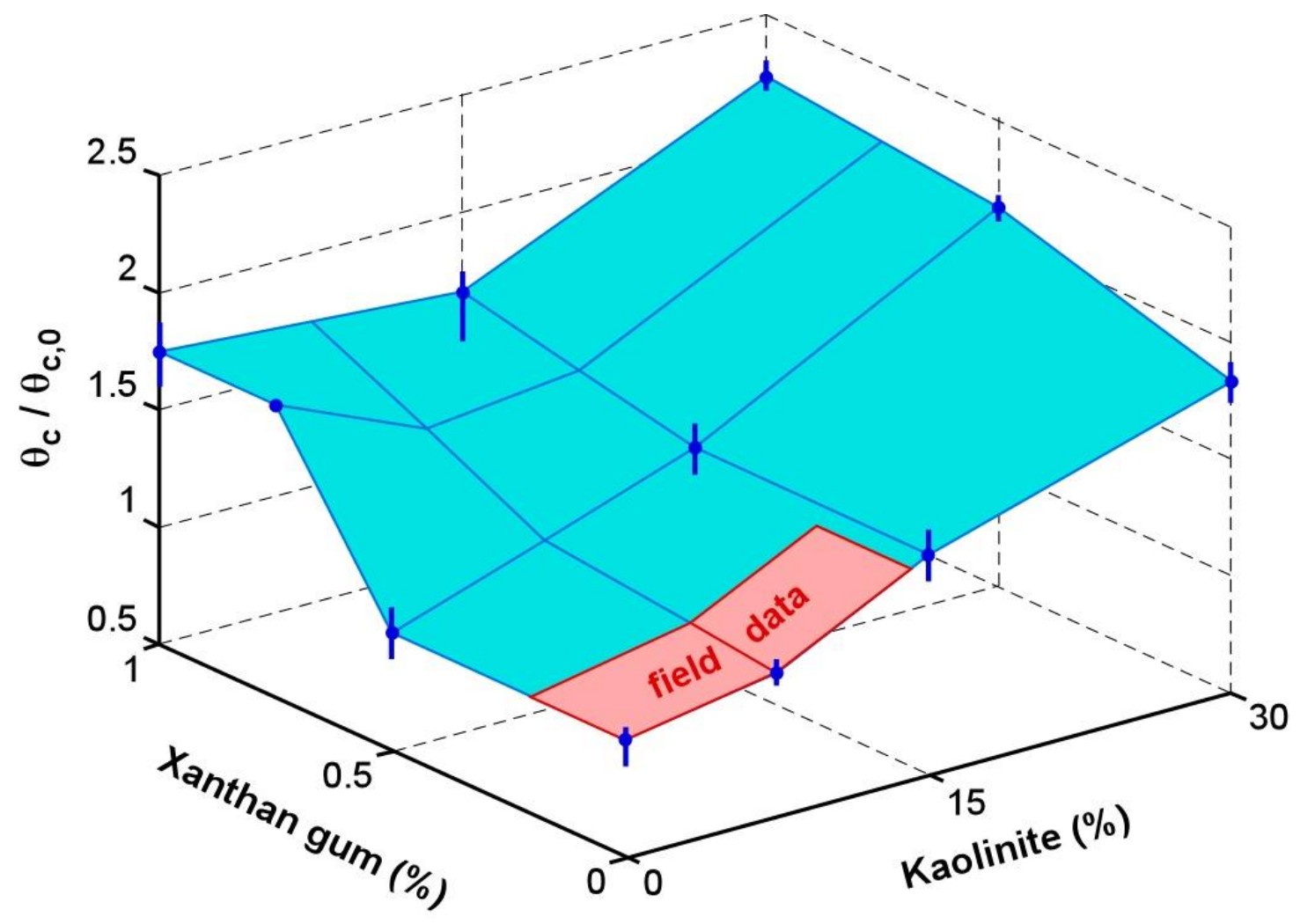

Fig. 7. Relative change in critical Shields parameter (including standard error) for sand with kaolin clay, sand with EPS-proxy xanthan gum, and sand with mixtures of kaolin and xanthan gum. The term $\theta_{c, 0}$ on the vertical axis denotes the critical Shields parameter for pure sand with a median grain diameter of $0.148 \mathrm{~mm}$. The blue coloured surface denotes the laboratory data. The red coloured insert denotes the approximate range of the field data.

\section{Implication for geological studies}

Whilst not a strong indicator of depositional environment, current ripples and their primary current lamination have been used extensively for the reconstruction of depositional processes in the geological record (e.g., Stow, 2005). The equilibrium height and length of current ripples increase, as the median size of the sediment particles in the bed increases, but their equilibrium dimensions are independent of flow strength (Baas, 1994). Instead, flow strength accelerates the development 
towards equilibrium height and length. On their way to linguoid equilibrium shape, current ripples go through distinct plan morphologies, i.e., incipient, straight-crested, sinuous, and non-equilibrium linguoid (Baas, 1994). This progressive increase in three-dimensionality has been used to determine the development stage of current ripples in deep-marine and shallow-marine environments (e.g., Baas, 1993, Oost \& Baas, 1994). However, reconstructing flow strength from the size and shape of non-equilibrium current ripples in clean sand has been challenging, because Equations 4 and 5 show that the formation of non-equilibrium ripples also includes a time factor. For example, the presence of underdeveloped straight-crested ripples and associated tabular cross-lamination may signify low flow strengths of relatively long duration, but also high flow strengths of very short duration. The present study shows that physical and biological cohesion push current ripples further away from 3D towards 2D shapes, unless flow strengths are high enough to successfully winnow the clay and EPS from the bed. Above all, a full recognition of the importance of cohesive forces for bedform dynamics, even at low bed clay and EPS fractions, requires a paradigm shift in sedimentary facies analysis. The boundary between clean sand (Shepard, 1954) or mature sandstone ('arenite' of Folk, 1951, and Dott, 1964) and dirty sand (Shepard, 1954) or immature sandstone ('wacke' of Folk 1951, and Dott, 1964) needs to be redefined. This new boundary should divide muddy sand from sand in which the detrital clay and associated EPS content are too low to significantly affect the geotechnical properties, and do this better than the arbitrarily chosen and disproportionately high boundaries of $25 \%$ clay of Shepard (1954) and 10-15\% of Folk (1951) and Dott (1964). As before, detrital clay content in sediments and sedimentary rocks should inform this new boundary, because it is unlikely that EPS are preserved in sedimentary rocks. We propose a modified boundary between mature and immature sand of $3 \%$ detrital clay; this limits the effect of cohesion to a c. $20 \%$ reduction in $\Lambda$ (Fig. 6) and a c. $8 \%$ increase in $\theta_{c}$ (Fig. 7). At the study site, $3 \%$ detrital clay was equivalent to $8 \%$ mud ( $<0.063 \mathrm{~mm}$; Equation 2$)$, and a size fraction $<0.030 \mathrm{~mm}$ of $7 \%$, which was used to define matrix sediment by Folk (1951) and Dott (1964). Further work is needed to verify if these new boundaries are applicable beyond the limits of the present comparative laboratory and field study.

As the development of current ripples in mixed sand-clay involves loss of clay and EPS by winnowing, facies analysis should not use the clay content within current ripples and ripple cross-laminated sand to relate current ripple size and shape to bed cohesion and hydrodynamic forcing. However, the clay content in the sediment immediately below the base of current ripples and sets of cross-lamination may in many cases be representative for the original bed clay content from which the ripples were generated, especially if the textural properties of the sediment - other than the clay content - are similar. On intertidal flats in estuaries, the field data show that time is an important limiting factor for the formation of current ripples. Following on from the above interpretations for mixed sand-clay in 
modern estuaries, the presence of 3D current ripples and trough cross-lamination in intertidal sandstones with more than c. $12 \%$ clay requires extraordinary processes of formation, such as combinations of spring tides within the macrotidal range, promotion of bedload transport by nearbed wave stress, close proximity to sandy tidal channels, and a large number of consecutive tidal cycles of slow ripple growth without destructive processes. Under normal circumstances, however, such clay-rich sandstones are expected to be associated with a total absence of current ripples or with small, 2D, straight-crested current ripples and tabular cross-lamination, whereas fully developed linguoid current ripples and their cross-lamination should dominate sandstones that are poor in cohesive clay. Based on the data presented (Figs 4 and 6), the 3\% detrital clay defined above for the boundary between mature and immature sand in the subsurface might also be an appropriate upper boundary for the presence of 3D ripples and their cross-lamination in sedimentary facies associated with tidal flats in macrotidal estuaries. This maximum in clay content is inferred to get progressively lower with decreasing tidal range in mesotidal and microtidal estuaries, with an increasing probability of finding sedimentary facies with 2D current ripples and their cross-lamination or no ripples at all. Moreover, clay-poor 3D current ripples are expected to be more common in tidal flat facies that are close to tidal channel facies, where tides accelerate owing to ebb and flood flow confinement.

\section{CONCLUSIONS}

This validation study shows that laboratory experiments on current ripple development in mixed sandclay-EPS are a suitable analogue for current ripple development on mixed sand-clay-EPS intertidal flats, and possibly also in other environments where physical and biological cohesion influence sediment erosion, transport, and deposition. The comparison between the field and laboratory data has led to the following main conclusions:

- Current ripples in sand develop at an increasingly slower rate, as progressively larger volumes of cohesive clay are mixed into the sand.

- These current ripples tend to become smaller and change from three-dimensional linguoid to twodimensional straight-crested, as bed clay content is increased.

- These findings demonstrate that clay starts to affect bedform dynamics in sandy sediment at much lower concentrations than the definitions of 'clean sand' and 'arenite' of Shepard (1954) and Folk (1951) implicate. A revised boundary of $3 \%$ detrital clay, equivalent to $7 \%$ matrix sediment with a grain size $<0.030 \mathrm{~mm}$, appears more appropriate for the onset of bed stabilisation by cohesive forces in the seabed.

- EPS might have a similar, yet stronger, effect on the size and planform of current ripples than clay. 
- Surface water waves may accelerate bedform development, but waves were too weak to explain any of the difference in the relationship between ripple length and bed clay content in this study.

- Clay type had a small influence on current ripple development in mixed sand-clay-EPS, because these bedforms were generated mostly at bed clay contents for which the rheological differences between clay mineral types are small.

- Differences in cumulative flow forcing need to be accounted for in comparisons of the dynamics of current ripples in mixed sand-clay between field and laboratory.

- Pore water salinity is also expected to control bedform development in mixed sand-clay-EPS, but quantification of this influence requires further study.

- These findings have important implications for predicting current ripple properties from hydrodynamic data in hydraulic engineering and for reconstructing flow properties from current ripple size and shape in sedimentary geology.

\section{ACKNOWLEDGEMENTS}

This work was supported by the UK Natural Environment Research Council (NERC) under grant NE/I027223/1 (COHBED). We are grateful to the NOC Ocean Technology and Engineering group, and field technicians from the University of Plymouth and Bangor University for instrument set up and deployment. David Paterson received funding from the Marine Alliance for Science and Technology for Scotland (MASTS), funded by the Scottish Funding Council (grant reference HR09011) and contributing institutions. Andrew Manning's contribution to this manuscript was partly funded by HR Wallingford Company Research project 'FineScale - Dynamics of Fine-grained Cohesive Sediments at Varying Spatial and Temporal Scales' (DDY0523). Renata Rocha kindly assisted with the field data collection as part of the Science Without Borders student exchange programme between Brazil and the UK.

\section{REFERENCES}

Amos, C.L., Droppo, I.G., Gomez, E.A. and Murphy, T.P. (2003) The stability of a remediated bed in Hamilton Harbour, Lake Ontario, Canada. Sedimentology, 50, 149-168.

Baas, J.H. (1993) Dimensional analysis of current ripples in recent and ancient depositional environments. Geologica Ultraiectina, 106, 199 pp. 
Baas, J.H. (1994) A flume study on the development and equilibrium morphology of small-scale bedforms in very fine sand. Sedimentology, 41, 185-209.

Baas, J.H. (1999) An empirical model for the development and equilibrium morphology of current ripples in fine sand. Sedimentology, 46, 123-138.

Baas, J. H., van Dam, R.L. and Storms, J.E.A. (2000) Duration of deposition from decelerating highdensity turbidity currents. Sedimentary Geology, 136, 71-88.

Baas, J.H., Davies, A.G. and Malarkey, J. (2013), Bedform development in mixed sand-mud: The contrasting role of cohesive forces in flow and bed. Geomorphology, 182, 19-39.

Baas, J.H., Best, J.L. and Peakall, J. (2016) Predicting bedforms and primary current stratification in cohesive mixtures of mud and sand. Journal of the Geological Society, 173, 12-45.

Baker, M., Baas, J.H., Malarkey, J., Silva Jacinto, R., Craig, M., Kane, I. and Barker, S. (2017) The effect of clay type on the properties of cohesive sediment gravity flows and their deposits. Journal of Sedimentary Research, 87, 1176-1195.

Brown, J.M. and Wolf, J. (2009) Coupled wave and surge modelling for the eastern Irish Sea and implications for model wind-stress. Continental Shelf Research, 29, 1329-1342.

Chen, X.D., Zhang, C.K., Paterson, D.M., Thompson, C.E.L., Townend, I.H., Gong, Z., Zhou, Z. and Feng, Q. (2017) Hindered erosion: The biological mediation of noncohesive sediment behaviour. Water Resources Research, DOI: 10.1002/2016WR020105.

Dalrymple, R.W. and Choi, K. (2007) Morphologic and facies trends through the fluvial-marine transition in tide-dominated depositional systems: A schematic framework for environmental and sequence-stratigraphic interpretation. Earth-Science Reviews, 81, 135-174.

Debnath, K., Nikora, V., Aberle, J., Westrich, B. and Muste, M. (2007) Erosion of cohesive sediments: Resuspension, bed load, and erosion patterns from field experiments. Journal of Hydraulic Engineering, 133, 508-520.

Dott Jr., R.L. (1964) Wacke, greywacke and matrix - What approach to immature sandstone classification? Journal of Sedimentary Petrology, 34, 625-632.

Folk, R. L. (1951) Stages of textural maturity in sedimentary rocks. Journal of Sedimentary Petrology, 21, 127-130.

Fox, D. (2000) Cohesive sediment dynamics on a mudflat within the macrotidal Conway Estuary, North Wales, UK. PhD Thesis, University of Wales Bangor, 104pp. 
Grabowski, R.C., Droppo, I.G. and Wharton, G. (2011) Erodibility of cohesive sediment: The importance of sediment properties. Earth-Science Reviews, 105, 101-120.

Grant, W.D. and Madsen, O.S. (1979) Combined wave and current interaction with a rough bottom. Journal of Geophysical Research, 84 (C4), 1797-1808.

Hillel, D. (2004) Introduction to Environmental Soil Physics. Elsevier Academic Press, Amsterdam, 494 pp.

Kandiah, A. (1974) Fundamental aspects of surface erosion of cohesive soils. PhD Thesis, University of California, Davis, 236 pp.

Lichtman, I.D., Baas, J.H., Amoudry, L.O, Thorne, P.D., Malarkey, J., Hope, J.A., Peakall, J., Paterson, D.M., Bass, S.J., Cooke, R.D., Manning, A.J., Parsons, D.R. and Ye, L. (in review) Bedform migration in a mixed sand-mud intertidal environment and implications for bed material transport predictions. Geomorphology.

Malarkey, J. and Davies, A.G. (2012) A simple procedure for calculating the mean and maximum bed stress under wave and current conditions for rough turbulent flow based on Soulsby and Clarke's (2005) method. Computers \& Geosciences, 43, 101-107.

Malarkey, J., Baas, J.H., Hope, J.A., Aspden, R.J., Parsons, D.R., Peakall, J., Paterson, D.M., Schindler, R., Ye, L., Lichtman, I.D., Bass, S.J., Davies, A.G., Manning, A.J. and Thorne, P.D. (2015) The pervasive role of biological cohesion in bedform development. Nature Communications, 6:6257, doi: 10.1038/ncomms7257.

Manning, A.J., Friend, P.L., Prowse, N. and Amos, C.L. (2007) Estuarine mud flocculation properties determined using an annular mini-flume and the LabSFLOC system. Continental Shelf Research, 27, 1080-1095.

McCrone, A.W. (1962) Clarification of the "winnowing" concept in geology. GSA Bulletin, 73, 517-518.

Mehta, A.J. (2013) An Introduction To Hydraulics Of Fine Sediment Transport. World Scientific Publishing Company, Advanced Series on Ocean Engineering, 38, 1060 pp.

Mitchener, H and Torfs, H. (1996) Erosion of mud/sand mixtures. Coastal Engineering, 29, 1-25.

Moore, D.M. and Reynolds Jr., R.C. (1997) X-Ray Diffraction and the Identification and Analysis of Clay Minerals, 2nd Edition. Oxford University Press, New York, 400 pp.

Moore, R.D., Wolf, J. Souza, A.J. and Flint, S.S. (2009) Morphological evolution of the Dee Estuary, Eastern Irish Sea, UK: A tidal asymmetry approach. Geomorphology, 103, 588-596. 
Oost, A.P. and Baas, J.H. (1994) The development of small scale bedforms in tidal environments: An empirical model and its applications. Sedimentology, 41, 883-903.

Parchure, T.M. and Mehta, A.J. (1985) Erosion of soft cohesive sediment deposits. Journal of Hydraulic Engineering, 111, 1308-1326.

Parsons, D.R., Schindler, R.J., Hope, J.A., Malarkey, J., Baas, J.H., Peakall, J., Manning, A.J., Ye, L., Simmons, S., Paterson, D.M., Aspden, R.J., Bass, S.J., Davies, A.G., Lichtman, I.D. and Thorne, P.D. (2016) The role of bio-physical cohesion on subaqueous bedform size. Geophysical Research Letters, 43, 1566-1573.

Perillo, M.M., Best, J.L. and Garcia, M.H. (2014) A new phase diagram for combined-flow bedforms. Journal of Sedimentary Research, 84, 301-313.

Raudkivi, A.J. (1997) Ripples on stream bed. Journal of Hydraulic Engineering, 123, 58-64.

Shields, A. (1936) Anwendung der Ähnlichkeitsmechanik und der Turbulenzforschung auf die Geschiebebewegung. Mitteilungen der Preussischen Versuchsanstalt für Wasserbau und Schiffbau, 26, $1-26$.

Schindler, R.J., Parsons, D.R., Ye, L., Hope, J.A., Baas, J.H., Peakall, J., Manning, A.J., Aspden, R.J., Malarkey, J., Simmons, S., Paterson, D.M., Lichtman, I.D., Davies, A.G., Thorne, P.D. and Bass, S.J. (2015) Sticky stuff: Redefining bedform prediction in modern and ancient environments. Geology, 43, 399-402.

Shepard, F.P. (1954) Nomenclature based on sand-silt-clay ratios. Journal of Sedimentary Petrology, 24, 151-158.

Soulsby, R. (1997) Dynamics of Marine Sands: A Manual for Practical Applications. Thomas Telford Ltd., London, 272 pp.

Soulsby, R.L. and Clarke, S. (2005) Bed Shear-stresses Under Combined Waves and Currents on Smooth and Rough Beds. Report TR 137, HR Wallingford, 52 pp.

Soulsby, R.L. and Whitehouse, R.J.S. (2005) Prediction of Ripple Properties in Shelf Seas; Mark 2 Predictor for Time Evolution. Report TR 154, Release 2.0, HR Wallingford, 99 pp.

Spears, B.M., Saunders, J.E., Davidson, I. and Paterson, D.M. (2008) Microalgal sediment biostabilisation along a salinity gradient in the Eden Estuary, Scotland: Unravelling a paradox. Marine and Freshwater Research, 59, 313-321.

Stow, D.A.V. (2005) Sedimentary Rocks in the Field: A Colour Guide. Manson, London, 320 pp. 
Tolhurst T.J., Black K.S. and Paterson D.M. (2009) Muddy sediment erosion: Insights from field studies. Journal of Hydraulic Engineering, 135, 73-87.

Torfs, H. (1995) Erosion of mud/sand mixtures. PhD Thesis, Katholieke Univeriteit Leuven, Faculteit der Toegepaste Wetenschappen, Departement Burgelijke Bouwkunde, Laboratorium voor Hydraulica, Belgium.

Underwood, G.J.C. and Paterson, D.M. (2003) The importance of extracellular carbohydrate production by marine epipelic diatoms. Advances in Botanical Research, 40, 183-240.

Van de Lageweg, McLelland, S.J. and Parsons, D.R. (2017) Quantifying biostabilisation effects of biofilm-secreted and synthetic extracellular polymeric substances (EPS) on sand substrate. Earth Surface Dynamics, Discussions, https://doi.org/10.5194/esurf-2017-59.

Van den Berg, J.H. (1987) Bedform migration and bed-load transport in some rivers and tidal environments. Sedimentology, 34, 681-698.

Van den Berg, J.H., Boersma, J.R. and van Gelder, A. (2007) Diagnostic sedimentary structures of the fluvial-tidal transition zone - Evidence from deposits of the Rhine and Meuse. Netherlands Journal of Geosciences, 86, 287-306.

Van Ledden, M. (2001) Modelling of sand-mud mixtures. Part II: A process-based sand-mud model. Delft Hydraulics, Report Z2840, 75 pp.

Van Rijn, L.C. (1990) Principles of Fluid Flow and Surface Waves in Rivers, Estuaries, Seas and Oceans. Aqua Publications, Amsterdam, 335 pp.

Van Rijn, L.C. (1993) Principles of Sediment Transport in Rivers, Estuaries and Coastal Seas, Part I: Edition 1993. Aqua Publications, Amsterdam, 673 pp.

Villaret, C., Huybrechts, N., Davies, A.G. and Way, O. (2011), Effect of bed roughness prediction on morphodynamic modelling: Application to the Dee estuary (UK) and to the Gironde estuary (France). In: Proceedings of $34^{\text {th }}$ IAHR World Congress, Brisbane, Australia, p. 1149-1156.

Yong, R.N., Nakano, M., and Pusch, R. (2012) Environmental Soil Properties and Behavior. CRC Press, London, $455 \mathrm{p}$. 


\section{APPENDIX A - DESCRIPTION OF CRITICAL SHEAR STRESS EXPERIMENTS}

The 'vertical shear flume' (Hydrodynamics Laboratory, Bangor University; Fox, 2000) was used to estimate the critical shear stress for sediment motion from beds comprising mixed sand-clay-EPS (Fig. 7). This flume consists of a straight, rectangular, channel, $1.2 \mathrm{~m}$ long and $0.18 \mathrm{~m}$ wide, with a water depth of $0.12 \mathrm{~m}$, through which fresh water was recirculated by a variable-speed pump. A blockshaped sediment box was slotted onto the bottom of the channel, ensuring that the surface level of the sediment in the box was flush with the floor of the channel. The sediment column within the box was $0.14 \mathrm{~m}$ long, $0.1 \mathrm{~m}$ wide, and $0.1 \mathrm{~m}$ deep. Downstream of this box, a bedload trap collected sediment particles moving along the bottom of the flume in flows that exceeded the critical shear stress for sediment motion.

The experiments were conducted with well-sorted, fine sand $\left(D_{50}=0.142 \mathrm{~mm}\right)$ mixed with $0-1 \%$ xanthan gum (EPS proxy), 0-30\% kaolin clay, or a mixture of up to $30 \%$ kaolin and up to $1 \%$ xanthan gum. In each experiment, steady, uniform flow was started well below the critical shear stress for the pure sand and then increased in small steps every 10 minutes. Streamwise flow velocities were measured with a vertical stack of five ultrasonic Doppler velocimetry (UVP) probes. Bed shear stresses were calculated from the UVP data by squaring the friction velocity determined from standard logarithmic law of the wall techniques (e.g., van Rijn, 1990). Water samples were taken periodically to determine suspended sediment concentrations, using the standard weighing and drying method, such that an optical backscatter (OBS) instrument, which was continuously recording, could be calibrated. For each sand-clay-EPS mix, the critical bed shear stress was determined by a combination of three methods: (1) visual observation of the erosion of sand grains from the sediment surface; (2) initiation of infilling of the bedload trap; and (3) the first signifciant increase in the concentration of suspended sediment. All critical bed shear stresses, relative to the critical bed shear stress for the pure sand, are shown in Fig. 7. 